\title{
WPLYW CZYNNIKÓW WEWNĘTRZNYCH I ZEWNĘTRZNYCH NA ROZWÓJ TERRORYZMU W AZJI CENTRALNEJ ${ }^{1}$
}

W 1991 r. w newralgicznym obszarze pomiędzy Rosją, ChRL, Iranem, subkontynentem indyjskim wyłoniło się pięć nowych państw środkowoazjatyckich: Kazachstan, Kirgistan, Tadżykistan, Turkmenistan oraz Uzbekistan. Wcześniej były one elementami składowymi Zawiązku Radzieckiego. Droga do niepodległości nie była wywołana ani przez powstanie zbrojne, irredentę, rewolucję, czy masowe demonstracje zorganizowanych przez opozycję. Zatem nie był to długotrwały i złożony proces wiodący do niepodległości. Przyszła ona dość niespodziewanie i przede wszystkim była możliwa przez rozpad Związku Radzieckiego. Elity polityczne w Azji Centralnej nie chciały występować przeciwko Związkowi Radzieckiemu, który dawał pewną stabilizację, a także dość skutecznie przeciwdziałał konfliktom o przebieg granic czy zasoby wodne. W latach 20. i 30. XX w. ustanawiając granice republik, decydenci radzieccy, celowo w ramach granic administracyjnych włączali regiony i obwody z innymi narodowościami. Rzymska zasada „dziel i rządź” miała być dodatkowym spoiwem dla utrzymania republik środkowoazjatyckich w strukturach ZSRR, dając władzom radzieckim możliwość bycia arbitrem rozwiązującym różne spory. $Z$ tego względu po rozpadzie ZSRR, obok problemów natury gospodarczej wystapiły te o charakterze etnicznym. Mniejszości m.in. uzbecka w Kirgistanie, Karakałpaków w Uzbekistanie i spora rosyjska w Kazachstanie mogły być detonatorem dla świeżo uzyskanej niepodległości. W czasach stalinowskich nie wahano się przed przymusową deportacją całych narodów.

Nowy region znajdujący się między Iranem, Pakistanem oraz Afganistanem od samego początku narażony był na przenikanie nurtów radykalnego islamu, a także jego najradykalniejszej postaci - terroryzmu. Pojęcie to nastręcza sporo problemów definicyjnych, w regionie Azji Centralnej można mówić o różnych postaciach terroryzmu, a mianowicie: narkoterroryzmie, dżihadyzmie, etnoterroryzmie czy islamskim terroryzmie. Niejednokrotnie pojęcia te stosowane są zamiennie, a także ,nachodzą na siebie", np. jednym ze źródeł finansowania grup (dżihadystycznych w tym etnoseparatystycznych) jest nielegalna produkcja i dystrybucja narkotyków.

Oceniając stopień zagrożenia terroryzmem w poszczególnych państwach jak i w skali całego regionu, należy zwrócić uwagę na następujące kwestie:

${ }^{1}$ Artykuł został przygotowany ramach projektu finansowanego przez Narodowe Centrum Nauki: Unia Europejska wobec Azji Środkowej - uwarunkowania regionalne i międzynarodowe, UMO-2014/15/B/HS5/01591. 
1) ideologia oraz cele grup terrorystycznych;

2) uwarunkowania wewnętrzne, jak i zewnętrzne wpływające na rozwój ugrupowań terrorystycznych;

3) rodzaje grup, ich aktywność oraz finansowanie.

Najbardziej zagrożone taką destabilizacją są: Uzbekistan ze względu na działalność Islamskiego Ruchu Uzbekistanu, Tadżykistan ze względu na potencjalne konflikty na tle etnicznym, radykalizm religijny oraz Kirgistan ze względu na konflikt etniczny (Fiedler, 2016: 226-243).

Ad. 1. Istotny wpływ na rozwój radykalizmu islamskiego ma wahabityzm. Zarówno pod względem ideologicznym, jak i organizacyjnym, zapleczem dla fundamentalizmu był ruch Talibów w Afganistanie. Fundamentalizm islamski w Azji Centralnej zaczynał się aktywizować już w czasach radzieckich. Po 1991 r. zaczął dynamicznie rozwijać się przede wszystkim w Tadżykistanie i Uzbekistanie. Z radykalnych środowisk wyrósł Islamski Ruch Uzbekistanu (dalej: IRU), który wpisywał się w salaficki radykalizm. Uzbekistan miał być zaczynem dla wzniecenia islamskiej rewolucji w regionie. Doszło do kilku nieudanych prób wzniecenia rewolucji islamskiej w Kotlinie Fergańskiej przez IRU (tzw. rajdy batkeńskie w 1999 i 2000 r.). Po tych próbach trzon IRU został przeniesiony do Afganistanu (Zapaśnik, 2006).

Rozwój radykalizmu islamskiego w regionie został przerwany w 2001 r. wraz z inwazją sił koalicji w Afganistanie, dowodzonych przez USA. Idąc na współpracę ze Stanami Zjednoczonymi, władze Kirgistanu, Tadżykistanu i Uzbekistanu zyskały potężne wsparcie ze strony USA do zwalczania fundamentalistów islamskich (Cooley, 1998: 183). W Uzbekistanie oraz Kirgistanie za zgodą władz tych państw powstały amerykańskie bazy wojskowe, które miały stanowić zaplecze do operacji ISAF w Afganistanie. Po walkach z siłami koalicji, IRU zmuszone zostało do ponownego przeniesienia swoich struktur do pakistańskiego Waziristanu i znalazło się w sieci pusztuńskich powiązań. Doszło wówczas do rozłamu - ze struktur IRU wyodrębniła się Islamska Unia Dżihadu (dalej: IUDż). Powstała na obszarze północnego Pakistanu sieć dżihadystyczna, której celem było nie tylko przeprowadzenie zamachów w Azji Centralnej, ale także w Europie. Bojownicy z IRU i IUDż byli uznawani za znacznie bardziej niebezpiecznych aniżeli talibowie (Lang, 2017: 1-7).

Powstanie tzw. Państwa Islamskiego (dalej: PI) w 2014 r. wyznacza kolejny istotny okres. Z szeregów IRU oraz IUDż do Syrii i Iraku przedostało się wielu bojowników. W 2015 r. przywódca IRU Usman Gazi ogłosił o przyłączeniu ruchu do PI. W wyniku walk z Talibami, zginął Usman Gazi. Talibowie nie uznali zwierzchności PI i doszło do rozłamów w ruchu dżihadystycznym. Po 2015 r. po odpływie bojowników oraz zmniejszeniu finansowania doszło do poważnego osłabienia struktur IRU i IUDż (Lang, 2015). Zarówno ideologia, jak i cele grup radykałów w Azji Centralnej uzależnione były od taktycznej współpracy z Talibami, salafitami i w ostatnim czasie z Państwem Islamskim. Uwzględniając różne deklaracje programowe i oświadczenia - radykalne grupy opowiadają się za „idealnym społeczeństwem” w ramach emiratu środkowoazjatyckiego, w którym wszelkie problemy społeczne oraz ekonomiczne zostałyby rozwiązane przez przestrzeganie szariatu. Tak formułowane dość ogólnikowe cele, stanowią odpowiedź radykałów na rosnące różnice społeczne, postępującą korupcję i autorytaryzm (Falkowski, Lang, 2015). 
Ad. 2. Całkowita powierzchnia Azji Centralnej wynosi $4 \mathrm{mln} \mathrm{km}^{2}$, a liczba ludności dochodzi prawie 60 milionów. Na tym obszarze występuje ponad 130 różnych ludów i grup etnicznych. Azja Centralna graniczy z Afganistanem $(2087 \mathrm{~km})$, Iranem $(922 \mathrm{~km})$, ChRL (2085 km), Federacją Rosyjską (6846 km). Jest jedynym obok Indonezji regionem na świecie, w którym występuje chrześcijaństwo, islam, konfucjanizm czy buddyzm (Mullerson, 2007: 234).

Przez wieki Azja Centralna była obszarem współwystępowania różnych grup etnicznych i wyznaniowych, które potrafiły ze sobą współegzystować bez poważniejszych napięć. Odrodzenie islamu w Azji Centralnej zaczęło być widoczne od połowy lat 80. XX w. Należy podkreślić, że w czasach radzieckich, mimo iż władzom udało się częściowo zmarginalizować islam w tym regionie, to jednak nie udało się go całkowicie wyeliminować. Rytuał religijny widoczny był w życiu codziennym, islam nadal odgrywał tradycyjną rolę w czasie narodzin, ślubu czy pochówku (Khalid, 2007). Islam tradycyjny zwany też „ludowym” nie niósł żadnych treści politycznych, a także nie miał ambicji wprowadzania rządów islamskich (Kozłowski, 2013: 282).

Po $1991 \mathrm{r}$. islam stał się jednym ze spoiw umożliwiających integrację społeczeństw w tym regionie. Dominuje islam sunnicki, muzułmanie przeważają w Turkmenistanie, Tadżykistanie i Uzbekistanie - odpowiednio 89\%, 85\% i 88\%. Natomiast w Kazachstanie i Kirgistanie, odsetek Muzułmanów w państwach osiagnął odpowiednio 70,2\% i 75\% (Rashid, 2003: 275).

Jedną z przeszkód, a zarazem zagrożeniem dla stabilności nowopowstałych republik środkowoazjatyckich stał się upolityczniony islam. Najbardziej podatne na radykalizm, a zarazem terroryzm są Tadżykistan oraz Uzbekistan. Z kolei najmniej podatne na rozwój radykalizmu są Kazachstan i Kirgistan. Turkmenistan ze względu na swoją specyfikę i zamknięcie, a także elementy totalitarnego systemu, stanowi najtrudniejszy przykład do analizy pod względem radykalizmu i terroryzmu. Pozostaje otwarta kwestia, na ile państwowy aparat kontroli i przemocy oraz polityka represji w wybranych państwach Azji Centralnej wpływa na radykalizację ludności.

Ocenę, którą organizację można uznać za terrorystyczną za każdym razem dokonują władze poszczególnych państw regionu. Najlepiej jest to uwidocznione na przykładzie Uzbekistanu. Władze tego państwa, korzystają z wygodnej formuły, że niemal każdy rodzaj opozycji ma znamiona zagrożenia terrorystycznego i należy ją zwalczać za pomocą najbardziej represyjnych środków (Moore, 2007: 303). Tego typu polityka oraz brak dialogu powoduje radykalizację części umiarkowanych grup. Okazuje się, że tego typu dość wygodna formuła także wykorzystywana jest przez pozostałe państwa regionu.

Mimo że w poszczególnych republikach środkowoazjatyckich występują pewne różnice, cechą wspólną tych państw jest silnie spersonalizowana władza wykonawcza, mniejszy lub większy brak wystarczającej ochrony prawnej oraz korupcja. Ponadto reformy polityczne uzależnione są od woli prezydenta. O ile w przypadku Kazachstanu dokonano wielu istotnych działan modernizacyjnych, o tyle w pozostałych przypadkach pozorne działania reformatorskie władz nie prowadzą do pogłębionej modernizacji (Shukuralieva, 2013).

Specyficznym obszarem, który jest najbardziej podatny na radykalizację i infiltrację ze strony różnych grup terrorystycznych i narkobiznesu, jest Kotlina Fergańska. 
Na obszarze tym, liczącym 124 tys. $\mathrm{km}^{2}$ i podzielnym pomiędzy Kirgistanem, Tadżykistanem i Uzbekistanem zamieszkuje aż 11 mln osób. Z powodu przeludnienia, ubóstwa, bezrobocia i braku wystarczającej infrastruktury jest jednym z najbardziej niestabilnych regionów w Azji Centralnej (Rashid, 2003: 193).

Tabela 1

Kotlina Fergańska - glówne punkty zapalne

\begin{tabular}{||l|l||}
\hline Kirgistan & Konflikty etniczne \\
\hline & $\begin{array}{l}\text { Miasto Osz - według danych z 1999 r. mniejszość uzbecka stanowiąca aż 49\% ludności. W ob- } \\
\text { wodach Osz i Dżalalabad 1/3 ludności stanowią Uzbecy. W Osz na początku lat 90. XX w. oraz } \\
\text { w } 2010 \text { r. doszło do starć. Konflikt w } 2010 \text { r. na tle etnicznym doprowadził według oficjalnych } \\
\text { danych do śmierci } 250 \text { i rannych } 2 \text { tys. osób oraz } 400 \text { tys. uchodźców. }\end{array}$ \\
\hline Uzbekistan & Problem ubóstwa \\
\hline Tadżykistan & $\begin{array}{l}\text { Do Uzbekistanu należy największa część kotliny. Na ubóstwo cierpi około 30\% ludności, } \\
\text { a skrajną nędzę ponad 9\%. }\end{array}$ \\
\hline & $\begin{array}{l}\text { Region Chodżentu w znacznej mierze zamieszkały przez Uzbeków. Konflikt tadżycko-uzbecki } \\
\text { był jednym z elementów wojny domowej w Tadżykistanie. }\end{array}$ \\
\hline
\end{tabular}

Źródło: Opracowanie własne na podstawie: Cierpiński (2009) oraz Sikorski (2010).

Problemy występujące w kotlinie nie tylko są wynikiem nieudolnie prowadzonej polityki przeciwdziałania ubóstwu, ale są także skutkiem polityki imperialnej Rosji i później ZSRR. Jej głównym celem było przeciwdziałanie potencjalnym tendencjom narodowym, jak i separatystycznym przez podzielenie i wymieszanie poszczególnych etnosów, także przy podziale Kotliny. W obrębie Uzbekistanu znalazła się mniejszość tadżycka, natomiast w Kirgistanie i Tadżykistanie - mniejszość uzbecka. Jak wiadomo, decydentom nie przeszkadzała historyczna awersja pomiędzy poszczególnymi przedstawicielami tych etnosów. Ponadto w systemie radzieckim, każda $\mathrm{z}$ republik miała określoną gospodarczą rolę do wypełnienia. Po 1991 r. skutki takiej polityki utrudniały i nadal utrudniają proces stabilizacji i normalizacji w tych państwach (Perkowska, 2011: 135-136).

Pierwszym generatorem radykalizmu i terroryzmu w Azji Centralnej okazał się Tadżykistan. Państwo pokryte pasmami górskimi w 90\%, odseparowane i najsłabiej przygotowane do niepodległości. Wojna domowa w latach 1992-1997 doprowadziła do śmierci 100 tys. osób i pojawienia się prawie 1,2 mln uchodźców. Wojna domowa w Tadżykistanie przybrała różne oblicza, była konfliktem między klanami Khojnet a Kulyab, etnicznym tadżycko-uzbeckim i wreszcie w szerszym oznaczała walkę pomiędzy postkomunistami a fundamentalistami muzułmańskimi. Nie bez znaczenia była talibizacja i wahabityzacja Afganistanu. Tadżyccy radykałowie mogli liczyć na współpracę z ruchem talibów w Afganistanie, na którego czele stanął Mullah Mohammad Omar. Z gościny talibów skorzystali fundamentaliści arabscy i dżihadyści z Osamą bin Ladenem i Aymanem al Zawahirim na czele. Radykalizacja religijna doprowadziła do zaangażowania innych aktorów zewnętrznych. Siły postkomunistyczne mogły liczyć na poparcie Rosji oraz Iranu (Hunter, 2012: 133-148). Ten ostatni w początkowym okresie nawet wspierał tadżycką Partię Odrodzenia Islamskiego, ale po nawiązaniu przez fundamentalistów tadżyckich współpracy z talibami, stanowiącymi zagrożenie ideologiczne, jak i zagrożenia dla bezpieczeństwa Iranu, władze 
irańskie zaangażowały się we wspieranie sił postkomunistycznych (Bojarczyk, 2008: 166-167). W Moskwie w 1997 r. doszło do porozumienia pomiędzy władzami a opozycją (Zjednoczona Opozycja Tadżycka) i jej przedstawiciele uzyskali 30\% stanowisk państwowych. Część opozycji nie zaakceptowała warunków porozumienia, schodząc do podziemia (Horsman, 2014).

Kolejnym sprzyjającym gruntem dla radykalizmu, jak i terroryzmu jest część Kotliny Fergańskiej należącej do Uzbekistanu. Najlepszym okresem dla rozwoju ugrupowań radykalnych, była chwilowa utrata przez władze kontroli nad niektórymi regionami. Utworzeniem ugrupowania Adolat (pol. Sprawiedliwość) w Namanganie zapoczątkowano organizowanie się nurtu fundamentalistycznego. Od początku radykałowie mieli sieć powiązań w Afganistanie, Pakistanie oraz na Bliskim Wschodzie. W 1998 r. założony został Islamski Ruch Uzbekistanu, który współpracował z Al-Kaidą. Jednak nie wszyscy uzbeccy dżihadyści opowiadali się za rozwijaniem globalnej sieci. Z inicjatywy Najmiddina Jalolova, zwanym również Abu Yahya z IMU wyodrębniła się grupa Unii Islamskiego Dżihadu (dalej: UIDż), która zamierzała koncentrować swoją uwagę przede wszystkim na doprowadzeniu do upadku (Olcott, 2012: 290). Pomimo pewnych podziałów, rozbudowana sieć powiązań IMU stanowi najpoważniejsze, spośród radykalnych organizacji, zagrożenie dla całego regionu Azji Centralnej. W 2004 r. doszło do największych ataków terrorystycznych w Taszkiencie i w Bucharze przeprowadzonych przez członków Hizb ut-Tahrir, IMU oraz UIDż (Stein, 2012: 78). Dla władz Uzbekistanu poważnym wyzwaniem są także umiarkowani muzułmanie opowiadających się za ideą sprawiedliwości islamskiej. Zwalczając umiarkowaną opozycję, reżim uzasadnia to zagrożeniem terrorystycznym. Władze nie zawahały się użyć siły do krwawej pacyfikacji powstania w Andiżanie z 13 na 14 maja 2005 r. (Azhiben, 2008: 1-11).

Od samego początku, na kształtowanie się ruchu radykalnego w regionie miało wpływ wiele czynników zewnętrznych, takich jak:

- aktywność „misjonarzy” saudyjskich szerzących wahabicką interpretację islamu;

- niekończący się konflikt w Afganistanie i aktywność Talibów oraz Al-Kaidy. Afganistan jest zapleczem do finansowania terroryzmu z narkobiznesu;

- działalność służb wywiadowczych Pakistanu;

- oddziaływanie tzw. Państwa Islamskiego.

Muzułmańskie społeczności Uzbeków i Tadżyków uzyskały największe wsparcie finansowe z zewnątrz. Najbardziej zauważalnym efektem tego wsparcia był skokowy wzrost liczby nowowybudowanych meczetów i madras. Dla przykładu w 1993 r. w Uzbekistanie wybudowano prawie 6 tys. meczetów i madras, gdy jeszcze w $1989 \mathrm{r}$. było ich zaledwie 300. W latach 1989-1991 otworzono 2 tysiące nowych meczetów w Tadżykistanie (Yerekesheva, 2004: 584). Natomiast tak gwałtownego wzrostu nie odnotowano ani w Kazachstanie, ani w Kirgistanie. W przypadku tego pierwszego w latach 90. XX w. wybudowano 1402 meczety, z kolei tego drugiego do 1995 r. wybudowano 1000 meczetów (Karagiannis, 2005: 143).

Analizując różne dane na temat „ochotników” z Azji Centralnej, którzy zostali zrekrutowani przez tzw. Państwo Islamskie - liczby mogą budzić pewien niepokój. Problem ubóstwa - jak podkreśla część badaczy - może być jednym z głównych „sukcesów rekrutacyjnych" PI. Uwzględniając uśrednione dane, na obszarze Azji Centralnej 
9,1\% mieszkańców tego regionu żyje poniżej przyjętego progu ubóstwa 1,25 USD dziennie. Od początku konfliktu syryjskiego, czyli od 2011 r., szacuje się, że różnym radykalnym organizacjom udało się zrekrutować od 2 do 5 tysięcy ochotników z Azji Centralnej (Falkowski, Lang, 2015). Mimo że całkowita liczba osób z Azji Centralnej biorących udział w wojnie syryjskiej, jak i w Iraku jest wysoka, to jest niższa po uwzględnieniu per capita $\mathrm{w}$ porównaniu z państwami z Bliskiego Wschodu i Afryki Północnej.

Tabela 2

Osoby zrekrutowane przez PI w Azji Centralnej, Afryce Północnej i na Bliskim Wschodzie

\begin{tabular}{||l|l||}
\hline \multicolumn{1}{|c|}{ Azja Centralna } & \multicolumn{1}{c||}{ Stosunek 1/1 tys. } \\
\hline Kirgistan & $1 / 56$ tys. \\
\hline Tadżykistan & $1 / 40$ tys. \\
\hline Uzbekistan & $1 / 58$ tys. \\
\hline Bliski Wschód i Afryka Północna & \multicolumn{1}{c||}{ Stosunek 1/1 tys. } \\
\hline Jordania & $1 / 5300$ \\
\hline Liban & $1 / 6500$ \\
\hline Arabia Saudyjska & $1 / 18$ tys. \\
\hline Maroko & $1 / 22$ tys. \\
\hline
\end{tabular}

Źródło: Opracowanie własne na podstawie: Dyner, Legieć, Rękawek, 2015: 1-6.

Do Syrii najmniej napłynęło ochotników z Kazachstanu. Szacuje się, że do szeregów Państwa Islamskiego przystapiło około 250 Kazachów, połowa z tej liczby to kobiety, dzieci, a także inżynierowie, pielęgniarki, nauczyciele itd. Kazachowie nie migrują za pracą w takiej skali jak Tadżykowie czy Kirgizi. Nieco więcej w stosunku do liczby ludności (około 5,7 mln), napłynęło ochotników z Kirgistanu. Szacunki nie są zbyt dokładne i wahają się od 100 do 600 ochotników. W tej grupie dominują mężczyźni w wieku 22-28 lat. Większość, bo aż 95\% zrekrutowanych Kirgizów pochodzi z południowej części kraju i wywodzi się z mniejszości uzbeckiej. Natomiast Turkmenii stanowią stosunkowo liczną grupę około 360 ochotników, także Tadżykowie około 400 zrekrutowanych przez PI. Największą zrekrutowaną grupą, choć nie w stosunku do ludności, są Uzbecy. Szacuje się, że około 500 ochotników przystąpiło do Państwa Islamskiego, ale także do Al-Nusry (Dyner, Legieć, Rękawek, 2015: 1-6).

Nie tylko liczba ochotników, ale również miejsce „rekrutacji” informuje o stanie potencjalnych zagrożeń. Okazuje się, że najwięcej osób udało się zrekrutować w meczetach na obszarze Federacji Rosyjskiej. Najbardziej dogodną grupą docelową akcji rekrutacyjnej PI są migranci zarobkowi z Azji Centralnej - głównie Kirgizi, Tadżykowie i Uzbecy. Z dala od swych rodzin, a także społecznie wyobcowani. W $2016 \mathrm{r}$. na rynku rosyjskim zatrudnienie znalazło 0,6 mln Kirgizów, prawie milion Tadżyków oraz 1,5 mln Uzbeków (The Central Bank of Russia, 2016).

Ponadto, ze względu na rozbudowany aparat kontrolno-represyjny, taka akacja rekrutacyjna jest znacznie trudniejsza bezpośrednio w poszczególnych państwach regionu, z pewnymi wyjątkami, jak wspomniana Kotlina Fergańska. Na tym obszarze może rozwinąc się sieć dżihadystyczna, szczególnie po upadku PI, mogąca stanowić regionalne struktury dla grup terrorystycznych. W obecnej chwili skrajni radykało- 
wie nie mają rozbudowanych struktur. Pewne możliwości przeorganizowania stwarza Afganistan i Pakistan.

Ad. 3. Od 1998 r. działa Islamski Ruch Uzbekistanu. Organizacja na początku dążyła do obalenia reżimu Islama Karimowa, a następnie Szawchata Mirzijojewa. Inną odnogą IRU jest, wspomniana wcześniej, Unia Islamskiego Dżihadu. Zarówno jedna, jak i druga grupa ściśle współpracuje z Al-Kaidą. Liderzy obu grup zasiadają w tzw. Szurze - radzie Al-Kaidy, mającej głos doradczy w kwestiach politycznych i strategicznych dotyczących światowego ruchu dżihadu. Metody działania IRU to połączenie działań militarnych i terroryzmu. IRU współpracuje z Talibami. Był cenionym sojusznikiem w walce przeciwko siłom ISAF w Afganistanie. Komórki IRU przenikają do Kirgistanu i Tadżykistanu. 16 lutego 1999 r. przeprowadzony został jeden z najbardziej spektakularnych zamachów w Taszkiencie przed siedzibą rządu wysadzonych zostało sześć samochodów pułapek (Dyner, Legieć, Rękawek, 2015: 1-6).

Kolejną organizacją, która ma dość rozbudowane struktury w Kotlinie Fergańskiej jest Hizb ut-Tahrir, a właściwie Hizb ut-Tahrir al-Islam (pol. Partia Islamskiego Wyzwolenia). Organizacja ta została założona na Zachodnim Brzegu w 1953 r., ale z czasem jej działalność została zakazana przez państwa arabskie. Stąd jej aktywność w Azji Centralnej, a szczególnie w Kotlinie Fergańskiej. Metody organizacji bardziej koncentrują się na prowadzeniu akcji edukacyjnej, tak by powstały warunki do powstania rządów islamu.

Tabela 3

Organizacje islamskie działające na obszarze Azji Centralnej

\begin{tabular}{|c|c|}
\hline Nazwa organizacji & Miejsce aktywności \\
\hline Partia Wyzwolenia Islamu Hizb of Ut-Tahrir al-Islami & $\begin{array}{l}\text { Kazachstan, Kirgistan, Tadżykistan i Uz- } \\
\text { bekistan }\end{array}$ \\
\hline $\begin{array}{l}\text { Bractwo muzułmańskie (Jama’al.-Harakat Ikhwan al-Muslimeen } \\
\text { występuje pod różnymi nazwami jak - Jamiat al-Islah al-Ijtimai) }\end{array}$ & Kazachstan, Kirgistan, Tadżykistan \\
\hline Centrum Rozwoju Islamu & Osz w Kirgistanie \\
\hline Stowarzyszenie Adolat Adolatyushmasi & Namangan w Uzbekistanie \\
\hline Żołnierze kalifatu Dzhund al Caliphate & Uzbekistan \\
\hline Nawrócenie Towba & Kirgistan i Uzbekistan \\
\hline
\end{tabular}

Źródło: Opracowanie własne na podstawie: Rollins, Sun Wyler (2012).

Przez długi czas terroryzm omijał Kazachstan. Jednak i tam doszło do ataku samobójczego w Aktobe. Szacuje się, że od tamtego momentu w akcjach terrorystycznych i przypisywanych terrorystom, a przede wszystkim w operacjach antyterrorystycznych, zginęło co najmniej 40 osób. Także w Turkmenistanie 12-13 września 2008 r. w stolicy Aszchabadzie w walkach z użyciem m.in. czołgów, turkmeńskie siły porządkowe miały spacyfikować „grupki kryminalistów”. Skala operacji sugeruje jednak na znacznie poważniejsze zagrożenie, aniżeli aktywność kryminalna (Primbetov, Mukashev, 2016).

Po 2014 r. zauważalna jest aktywność bojowników z Azji Centralnej, którzy przewinęli się przez szeregi PI. Na razie są aktywni poza regionem. 7 kwietnia 2017 r. zamach w Sztokholmie przeprowadzony został przez obywatela Uzbekistanu. Natomiast 
3 kwietnia zamachu w metrze w Sankt Petersburgu dokonał Uzbek z Kirgistanu posiadający obywatelstwo rosyjskie. Wcześniej przeprowadzone zostały zamachy w Turcji, w które także zaangażowani byli radykałowie z Azji Centralnej.

Tabela 4

Największe akcje terrorystyczne przeprowadzone w Tadżykistanie i Uzbekistanie

\begin{tabular}{||c|c|c|l|c|c|c||}
\hline Data & Państwo & Miasto & \multicolumn{1}{c|}{ Grupa } & Zabici & Ranni & Cel ataku \\
\hline 3.09 .2010 & Tadżykistan & Khujand & IMU & 4 & 25 & Policja \\
\hline 30.07 .2004 & Uzbekistan & Taszkent & $\begin{array}{l}\text { Hizb al-Tahrir al-Islami (HT) (podej- } \\
\text { rzewany) IMU (podejrzewany) }\end{array}$ & 2 & 4 & $\begin{array}{c}\text { Obiekty } \\
\text { rządowe }\end{array}$ \\
\hline 30.07 .2004 & Uzbekistan & Taszkent & $\begin{array}{l}\text { Hizb al-Tahrir al-Islami (HT) (podej- } \\
\text { rzewany) IMU (podejrzewany) }\end{array}$ & 2 & 1 & $\begin{array}{c}\text { Obiekty } \\
\text { rządowe }\end{array}$ \\
\hline 30.07 .2004 & Uzbekistan & Taszkent & $\begin{array}{l}\text { Hizb al-Tahrir al-Islami (HT) (podej- } \\
\text { rzewany) IMU (podejrzewany) }\end{array}$ & 3 & 1 & $\begin{array}{c}\text { Obiekty } \\
\text { rządowe }\end{array}$ \\
\hline
\end{tabular}

Źródło: Opracowanie na podstawie: Global Terrorism Database (2017).

Na rozwój grup przestępczych, jak i terrorystycznych wpływ mają dochody z przemytu narkotyków. Dla przykładu 90 z 365 ton afgańskiej heroiny, które zostało przetransportowane w 2012 r. przez Azję Centralną, 90\% z tego transportu zostało przerzucone przez terytorium Federacji Rosyjskiej do Europy. Na podstawie danych z World Drug Report 2012, można przyjąć, że produkcja heroiny sięga 5800 ton, co stanowi aż 61\% produkcji światowej (World Drug Report, 2013: 2). Rozwój infrastruktury komunikacyjnej umożliwił zwiększenie przemytu narkotyków. Obecnie funkcjonuje co najmniej 9 oficjalnych przejść granicznych pomiędzy Afganistanem a państwami regionu Azji Centralnej, w tym most „przyjaźni” przez rzekę Amu Darię. Przez most dziennie przejeżdża 1000 pojazdów, gdy przez promy rzeczne można było transportować jedynie 40 ciężarówek dziennie. Afganistan ze swoją specyfiką oraz siecią powiązań etnicznych, bowiem na jego terytorium znajduje się $27 \%$ Tadżyków, 9\% Uzbeków oraz 3\% Turkmenów, tworzy rozbudowaną sieć przemytniczą i powiązania rodzinno-klanowe z regionem Azji Centralnej (Rollins, Sun Wyler, 2012: 3).

$$
* * *
$$

Współwystępowanie czynników wewnętrznych, jak i zewnętrznych mają wpływ na radykalizację i aktywność grup terrorystycznych. Od samego początku Azja Centralna znalazła się pod przemożnym wpływem radykalizmu sunnickiego, którego propagatorzy to Talibowie oraz fundamentaliści i idee napływające szczególnie z Arabii Saudyjskiej. W okresie 1991-2001 radykałowie mieli rozbudowane struktury w Uzbekistanie i Tadżykistanie, a także sieć powiązań z Talibami. Stanowili realną siłę i zagrożenie dla poszczególnych państw regionu. Zaangażowanie militarne sił koalicji dowodzonych przez USA w Afganistanie, a także bliska współpraca z władzami kirgiskimi i uzbeckimi, doprowadziło do poważnego osłabienia grup terrorystycznych, takich jak IRU, zmuszonych poszukiwać schronienia w północnym Pakistanie. Mimo przeprowadzonych zamachów terrorystycznych w 2004 r., grupy terrorystyczne nie miały możliwości na wzmocnienie swoich struktur w re- 
gionie. Obecnie państwa regionu mogą liczyć na współpracę z Rosją, a przede wszystkim z ChRL, która sama zwalcza tendencje separatystyczne Ujgurów w prowincji Xinjiang.

Po 2014 r. najbardziej podatną grupą na rekrutację do PI okazali się migranci zarobkowi z Azji Centralnej, którzy znaleźli zatrudnienie w Rosji. Obecnie bojownicy głównie Uzbecy, jak i Kirgizi zasilają sieć dżihadystyczną, która przeprowadza zamachy poza regionem Azji Centralnej. Nie oznacza to, że zagrożenie minęło. Przed państwami takimi jak Kirgistan, Tadżykistan, Uzbekistan, Turkmenistan i w mniejszym stopniu Kazachstan jest trudna droga modernizacyjna. Pewne reformy zostały już zainicjowane. Problem ubóstwa i zacofania w Kotlinie Fergańskiej tworzy ognisko zapalne, które jest wykorzystywane przez różne ugrupowania radykalne. Dochodzą jeszcze konflikty etniczne, a także przemyt narkotyków, który jest najbardziej dogodnym źródłem finansowania nie tylko zorganizowanej przestępczości, ale także działalności terrorystycznej. Korelacje czynników wewnętrznych (kryzysy) i zewnętrznych w postaci zorganizowanej sieci dżihadystycznej wraz z kanałami dystrybucji narkotyków dają dogodne warunki dla rozwoju terroryzmu w Azji Centralnej.

\section{BIBLIOGRAFIA}

Azhiben S. (2008), The Andijan Events: Radical Islam and Conflict in Uzbekistan, „Conflict \& Communication Online", Vol. 7, No. 1, http://www.cco.regener-online.de/2008_1/pdf/azhiben. pdf (20.05.2017).

Bojarczyk B. (2008), Działania Islamskiej Republiki Iranu w regionie, w: Region Azji Centralnej jako obszar wpływów międzynarodowych, (red.) B. Bojarczyk, A. Ziętek, Lublin.

Cierpiński Z. (2009), Kotlina Fergańska rozsadnik ,,narkoislamizmu”, http://www.psz.p1/116-bezpieczenstwo/kotlina-ferganska-rozsadnik-narkoislamizmu (13.05.2017).

Dyner A., Legieć A., Rękawek K. (2015), Ready to Go? ISIS and Its Presumed Expansion into Central Asia, „PISM Policy Paper”, No. 19 (121).

Falkowski M., Lang J. (2015), Homo Dżihadicus. Islam na obszarze byłego ZSRR a fenomen postsowieckich ochotników w Syrii i Iraku, „Raport OSW”, https://www.osw.waw.pl/sites/default/files/raport_homo_dzihadicus_net.pdf (20.06.2017).

Fiedler R. (2016), Zewnętrze i wewnętrzne czynniki niestabilności w Azji Centralnej, w: Unia Europejska wobec Azji Centralnej. Uwarunkowania regionalne i międzynarodowe, (red.) R. Fiedler, T. Wallas, Poznań.

Global Terrorism Database (2017), https://www.start.umd.edu/gtd/search/Results.aspx?search=isla mic + movement + of + uzbekistan\&sa. $x=36 \&$ sa. $y=14$ (20.05.2017).

Horsman S. (2009), Uzbekistan's involvement in the Tajik Civil War 1992-97: Domestic considerations, „Central Asia Survey”, Vol. 18, Issue 1, doi: 10.1080/02634939995731.

Hunter S. (2012), Iran's pragmatic regional policy, „Journal of International Affairs”, Vol. 56, No. 2.

Karagiannis E. (2005), Political Islam and Social Movement Theory: The Case of Hizb ut-Tahrir in Kyrgyzstan, „Religion, State and Society”, Vol. 33, No. 2.

Olcott M. B. (2012), In The Whirlwind Of Jihad, Washington, DC.

Khalid A. (2007), Islam after communism: religion and politics in Central Asia, Berkeley. 
Kozłowski K. (2013), Polityczny obraz islamu w poradzieckiej Azji Centralnej, w: Religia i polityka na obszarze Europy Wschodniej, Kaukazu i Azji Centralnej, (red.) T. Stępniewski, Lublin.

Lang J. (2015), Nerwowość w Azji Centralnej po zajęciu Kunduzu przez talibów, „Analizy OSW”, https://www.osw.waw.pl/pl/publikacje/analizy/2015-10-14/nerwowosc-w-azji-centralnejpo-zajeciu--kunduzu-przez-talibow (10.06.2017).

Lang J. (2017), Eksport dżihadu - terroryzm islamski z Azji Centralnej, „Komentarze OSW”, https:// www.osw.waw.pl/pl/publikacje/komentarze-osw/2017-04-12/eksport-dzihadu-terroryzmislamski-z-azji-centralnej (20.06.2017).

Moore C. (2007), Combating terrorism in Russia and Uzbekistan, „Cambridge Review of International Affairs", Vol. 20, No. 2.

Mullerson R. (2007), Central Asia. A chessboard and a player in the new great game, London.

Perkowska A. (2011), Przedradziecka tożsamość narodowa $w$ Azji Centralnej w kontekście polityki narodowościowej ZSRR, „Przegląd badań, Studia z Dziejów Rosji i Europy ŚrodkowoWschodniej”, zeszyt 1.

Primbetov D. S., Mukashev S. (2016), Terrorism in Central Asia and Kazakhstan and Information Warfare, http://www.globalmediajournal.com/open-access/terrorism-in-central-asia-andkazakhstan-and-information-warfare.php?aid=77776 (20.06.2017).

Rashid A. (2003), Dżihad. Narodziny wojujacego islamu w Azji Środkowej, Warszawa.

Rollins J., Sun Wyler L. (2012), Terrorism and Transnational Crime: Foreign Policy. Issues for Congress, „Congressional Research Service”, http://www.fas.org/sgp/crs/terror/R41004.pdf (10.06.2017).

Shukuralieva N. (2013), Globalny rozwój w kontekście społeczno-gospodarczych wyzwań Azji Środkowej i Kaukazu Poludniowego, Projekt współfinansowany przez Ministerstwo Spraw Zagranicznych RP w ramach programu Polska Pomoc, Bydgoszcz.

Stein M. (2012), Uzbekistan's View of Security in Afghanistan After 2014, „Military Review”, Vol. 92 , Issue 3.

The Central Bank of Russia (2016), http://www.cbr.ru/statistics/?Prtid=svs\&ch=Par_17101\#Checke dItem (10.07.2017).

World Drug Report (2013), United Nations Office on Drugs and Crime, https://www.unodc.org/unodc/secured/wdr/wdr2013/World_Drug_Report_2013.pdf(14.05.2017).

Yerekesheva L. (2004), Religious Identity in Kazakhstan and Uzbekistan: Global-Local Interplay, „Strategic Analysis”, Vol. 28, No. 4.

Zapaśnik S. (2006), ,Walczqcy Islam” w Azji Centralnej - problem społecznej genezy zjawiska, Wrocław.

\section{STRESZCZENIE}

W Azji Centralnej współwystępują czynniki zewnętrze, jak i wewnętrzne mające wpływ na rozwój terroryzmu. Szczególne sąsiedztwo z Afganistanem, jak i Pakistanem umożliwiają tworzenie sieci powiązań pomiędzy różnymi grupami. Kotlina Fergańska stanowi przykład czynników wewnętrznych, takich jak ubóstwo, brak odpowiedniej infrastruktury oraz konflikty etniczne jako odpowiedni grunt dla rozwoju terroryzmu.

Słowa kluczowe: terroryzm, radykalizm, Kotlina Fergańska, Islamski Ruch Uzbekistanu, Państwo Islamskie 


\title{
INTERNAL AND EXTERNAL FACTORS' IMPACT ON TERRORISM RISE IN CENTRAL ASIA
}

\begin{abstract}
In Central Asia co-occur external and internal factors, which are having impact on terrorism rise. Particularly neighborhood with Afghanistan and Pakistan enables a specific environment for a net connections and collaboration for radical groups. The Fergana Valley is an example of internal factors effect. The problem of poverty, lack of infrastructure and ethnic conflicts ease radicalism and terrorism rise.
\end{abstract}

Keywords: terrorism, radicalism, Fergana Valley, Islamic Movement of Uzbekistan, Islamic State 
